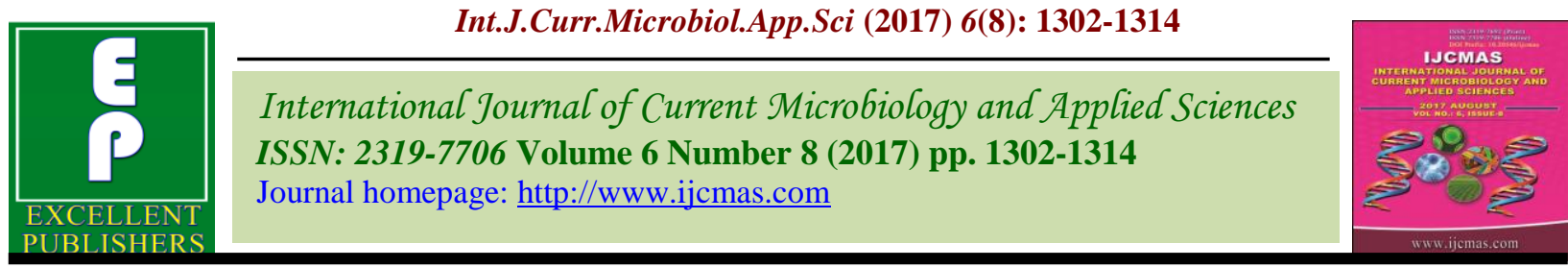

Review Article

https://doi.org/10.20546/ijcmas.2017.608.158

\title{
Edible Insects: Future Prospects for Dietary Regimen
}

\author{
Atanu Seni* \\ Orissa University of Agriculture and Technology, AICRIP, RRTTS, Chiplima, \\ Sambalpur-768025, Odisha, India \\ *Corresponding author
}

\section{A B S T R A C T}

Keywords

Ecological advantages, Entomophagy, Food security, Insect.

Article Info

Accepted:

17 June 2017

Available Online:

10 August 2017
Increasing world population pressure will create serious problem of food security in coming future. Entomophagy is the consumption of insects by humans, is practised in many countries around the world but predominantly in parts of Asia, Africa and Latin America yet it has not been fully used and developed as a food source. It has the potential of great interest as a possible solution due to their many advantages: (i) they are an important source of protein, fat, carbohydrate and other nutrients; (ii) their use as food has ecological advantages over conventional livestock and, in the long run, economic benefits; (iii) Their rich species diversity and large populations bring diversity in diet menu.

\section{Introduction}

The present world population of 7.2 billion is expected to increase by 1 billion over the coming 12 years and reach 9.6 billion by 2050. To accommodate this huge number, current food production will need to boost up almost double. Farming land is decreasing; climatic deviation and environmental pollution could have profound implications on food production. To meet the food and nutrition challenges of today, we need to find new ways of growing food.

Since the last 400 million years, evolution has produced much variety of arthropod species and helps many of them to adapt new environments. About 1 million of the 1.4 million described animal species on earth are insects, and millions more are believed to exist and within the 1 million described insect species, only 5000 are considered to be harmful to crops, livestock or human beings (Lenteren, 2006). Insects deliver a various ecological services which are fundamental to the survival of humankind. For instance, insects play a crucial role in plant reproduction. An estimated 100000 pollinator species have been identified and almost all of these (98 percent) are insects (Ingram et al., 1996). Over 90 percent of the 250000 flowering plant species depend on pollinators. Insects play an equally vital role by acting as scavenger. Beetle larvae (grub), flies, ants and termites break down the dead plant matter and helps to improvement of soil condition. By this process, the minerals and nutrients of dead organisms become simple available form 
for uptake by plants. Besides serving as pollinator and scavenger, insects provide humans with a variety of other valuable products. The most commonly known insect products used by human being are Honey and silk. Bees help to produce almost 1.2 million tons of commercial honey per year (FAO, 2009), while silkworms produce more than 90000 tonnes of silk (Yong-woo, 1999). In other way, scale insects (order Hemiptera) produced a red dye, known as Carmine used to colour foods, textiles, fashion and pharmaceuticals industry. Resilin, a rubberlike protein that enables insects to jump, has been used in medicine to repair arteries because of its elastic properties (Elvin et al., 2005; Van-Huis et al., 2013). Many insects also act as an important indicator of aquatic ecosystem health i.e. mayfly, stonefly, and caddisfly nymphs as their presence is a reliable indicator of a high quality oxygenated, less polluted water. Further these, insects are serving as sources of food. Edible insects have always been a part of human diets from very early date, but in some societies there is a degree of distaste for their consumption. It is found that the majority of edible insects are collected from forest habitats; innovation in mass-rearing systems has started recently in many countries. They contribute a significant opportunity to merge traditional knowledge and modern science in both developed and developing countries to become a part of dietary requirement in every society.

\section{Entomophagy around the world}

The practice of eating insects is known as entomophagy. Edible insects in many cultures have been eaten as staple or as a delicacy. However, in some societies there is a degree of distaste for their consumption. There are two main reasons behind the acceptance of eating insects: (1) the bad reputation they have as unhygienic and disease-spreading species; and (2) their association with the concept that they are only eaten in times of starvation or as a food source of primitive hunter-gatherer societies (MacEvilly, 2000; DeFoliart, 1999; Yen, 2010). Over 1500 species of insects are known to be consumed by humans from over 300 ethnic groups in 113 countries (MacEvilly, 2000) and it is estimated that insect-eating is practiced regularly by at least 2 billion people worldwide. Even an issue of the Food Insects Newsletter cited that 80 percent of the world's population eats insects intentionally and 100 percent eat them unintentionally. Globally, the most commonly eaten insects are beetles (Coleoptera) (31 percent) because of their large no of population almost 40 percent of all known insect species; followed by caterpillars, bees, wasps, ants, grasshoppers, locusts, crickets, cicadas, leaf and planthoppers, scale insects and true bugs, termites, dragonflies and flies. The consumption of caterpillars (Lepidoptera), especially popular in sub-Saharan Africa, is estimated at 18 percent. Bees, wasps and ants (Hymenoptera) come in third position and share is around at 14 percent (these are mostly common in Latin America). Following these are grasshoppers, locusts and crickets (Orthoptera) (13 percent); cicadas, leafhoppers, planthoppers, scale insects and true bugs (Hemiptera) (10 percent); termites (Isoptera) (3 percent); dragonflies (Odonata) (3 percent); flies (Diptera) (2 percent); and other orders (5 percent). Lepidoptera are consumed almost entirely as caterpillars and Hymenoptera are consumed mostly in their egg, larval or pupal stages. Both adults and larvae of the Coleoptera order are eaten, while the Orthoptera, Homoptera, Isoptera and Hemiptera orders are mostly eaten in the adult stage (Cerritos, 2009; Van Huis et al., 2013).

It is found that the most popular edible beetle in the tropics is the palm weevil, Rynchophorus, which is distributed 
throughout Africa, southern Asia and South America. The palm weevil $R$. phoenicis is found mainly in tropical and equatorial Africa, whereas $R$. ferrugineus is found in Asia (Indonesia, Japan, Malaysia, Papua New Guinea, the Philippines and Thailand) and another species $R$. palmarum found in the tropical Americas mainly Central America and West Indies, Mexico and South America. In the Netherlands, the larvae of mealworm species from the Tenebrionidae family, such as the yellow mealworm (Tenebrio molitor), the lesser mealworm (Alphitobius diaperinus) and the superworm (Zophobas morio), are reared as feed for reptile, fish and avian pets. They are also sells in specialized shops as human food for consumption (Van Huis et al., 2013).

In lepidopteran insect the mopane caterpillar (Imbrasia belina) is one of the most popular and economically important caterpillar consumed in different parts of African countries. One interesting fact that about 9.5 billion mopane caterpillars are harvested annually in southern Africa which value in monetary term is almost US\$85 million (Ghazoul, 2006). It is found that 38 different edible species of caterpillar are present across the Democratic Republic of the Congo, Zambia and Zimbabwe (Van Huis et al., 2013). Latham, 2003 documented 23 edible species in the Bas-Congo, a western province of the Democratic Republic of the Congo. In Asia, the bamboo caterpillar (Omphisa fuscidentalis), also known as the bamboo borer or bamboo worm, is a popular food that is being promoted by the Thai Department of Forestry of the Ministry of Agriculture and Cooperatives as an increasingly viable source of income (Yhoung-Aree and Viwatpanich, 2005). In the Chiapas region in Mexico, locals are believed to consume up to 27 caterpillar species, such as red maguey worms, larvae of the moth Comadia redtenbacheri and white maguey worms, larvae of the butterfly
Aegiale hesperiaris etc. (Van Huis et al., 2013). The Australian aborigines eat the Witchery grub, moth larvae (Xyleutes leuchmochla) that are reputed to taste like almonds (Srivastava, 1996; Yen, 2010).

Ants are very popular in different parts of the world due to their tasty delicacies (Rastogi, 2011; Del Toro et al., 2012). The larvae, pupae and eggs of weaver ant (Oecophylla spp.) constitute a popular diet in Asia. In Thailand they are mostly sold in cans. Shen et al., 2006 reported that the ant, namely black weaver ant (Polymachis dives) is widely distributed in China, Bangladesh, India, Malaysia and Sri Lanka and mainly used as a nutritional ingredient. They are also processed into various tonics or healthy foods. The value of ant is so high, even State Food and Drug Administration and State Health Ministry of China have approved more than 30 ant-containing health products since 1996. In Japan, the commonly consumed insect is the larvae of yellow jacket wasps (Vespula and Dolichovespula spp.), which is locally known as hebo. An inventory compiled by Ramos Elorduy and Pino (Ramos Elorduy and Pino, 2002) in Chiapas, Mexico, suggested that most insect species eaten in the state belong to the Hymenoptera order, and two leafcutter ant species (Atta mexicana and A. cephalotus) are very popular there (Van Huis et al., 2013).

In Orthopteran insects, almost 80 grasshopper species are consumed worldwide, and the large majority of grasshopper species are edible. Locusts may occur in swarms, which makes them particulary easy to catch. In Africa, different types of locust namely the desert locust, the migratory locust, the red locust and the brown locust are eaten. Grasshoppers and locusts are generally collected in the morning because of their sluggish nature at morning cool temperature. In Oaxaca, the harvest of chapulines (edible 
grasshoppers of the genus Sphenarium) only takes place very early in the morning (04:0005:00 hours) (Cerritos and Cano-Santana, 2008) because chapulines are too active and difficult to catch during the hotter part of the day (Cohen et al., 2009). The chapuline is probably the best-known edible grasshopper in Latin America also. This small grasshopper has been a part of local diets from very early times and is still serving as food in several parts of Mexico. The valleys of Oaxaca State in Mexico are especially famous for the consumption of chapulines. Cleaned and toasted in a little oil with garlic, lemon and salt for flavour, they are a common food ingredient among not only indigenous communities but also the urban population in Oaxaca city (Cohen et al., 2009). Another important edible insect in Mexico is Sphenarium purpurascens, which is a pest of alfalfa. Harvesters use conical nets (about 80 $\mathrm{cm}$ in diameter and $90 \mathrm{~cm}$ deep) without handles to lightly beat the alfalfa plants, allowing each local family to obtain about 50-70 kilograms $(\mathrm{kg})$ of grasshoppers weekly (Cerritos and Cano-Santana, 2008). Chapulines also play an effective role in local small-scale markets as well as in restaurants and export markets. A grasshopper called cone-headed grasshopper, Ruspolia nitidula is a delicacy among many tribes in Uganda and other central and eastern African countries as far as Zimbabwe. In Uganda, locally call them "nsenene". Introduction of electric street light into towns of East Africa has revolutionized their collection as the insects are attracted in so much vast numbers so that in Kampala (capital of Uganda), sometime streets are blocked to traffic by people coming from nearby rural areas for their collection (Srivastava, 1996). In Asia, the crickets namely Gryllus bimaculatus, Teleogryllus occipitalis and T. mitratus are collected in the wild and then consumed them. In Thailand, The house cricket (Acheta domesticus) is reared and commonly eaten as popular delicacies. In a study carried out in Thailand in 2002, 53 of 76 provinces had cricket farms (Yhoung-Aree and Viwatpanich, 2005; Van Huis et al., 2013). As of 2012, there were about 20000 cricket farmers in Thailand. Beside this, another cricket which is called short-tail cricket (Brachytrupes portentosus), which has a large body and large head, is also very popular for eating (Van Huis et al., 2013). In Japan, the most widely eaten insect is Oxya velox, a rice grasshopper, locally called "inago". Catching inago has a poetic charm in Japan. There some elementary schools arrange an imago hunt every year in which parents are also invited to participate with their wards. After collection, they are cooked and served. In markets, processed inago are sold in packets. Inago-hunting serves two purposes: provides animal protein and reduces the number of an agricultural pest (Srivastava, 1996).

In Malawi, several cicada species (Ioba, Platypleura and Pycna) are highly consumed as food. Some Homoptera yield products commonly used by humans, such as carmine dye (a bright red pigment also called E120) derived from the cactus cochineal bug (Dactylopius coccus) often used in food products. In South Africa the psyllid (Arytaina mopane) that sucks the phloem sap of the mopane tree (Colophospermum mopane) is eaten. The largest number of lerpbuilding (a crystallized, sugary secretion produced by the nymph of psyllid insects) insects are found on Eucalyptus trees in Australia. The Aborigines of Australian collect this lerp as a sweet food source (Yen, 2005; Van Huis et al., 2013). Different pentatomid bugs are consumed widely throughout sub-Saharan Africa, particularly in southern Africa. In the Republic of Sudan, the pentatomid Agonoscelis versicolor, a pest of rainfed sorghum that causes considerable damage, is eaten as roasted food. Sometimes, oil is also extracted from these insects and is 
used in preparing different food items and also used for treating scab disease in camels (Van Huis, 2003a). Mostly pentatomid aquatic bugs are consumed as food. The famous Mexican caviar, ahuahutle, is composed of the eggs of at least seven species of aquatic Hemiptera (the Corixidae and Notonectidae families); these insects have formed the backbone of aquatic farming, or aquaculture, in Mexico for centuries (Bachstez and Aragon, 1945).

The most commonly consumed termite species are the large Macrotermes species. Van Huis (Van Huis, 2003b) observed that, in Africa, locals beat the ground around termite hills (simulating heavy rain) to provoke the termites to emerge. In Amazon valley the most commonly eaten termites are Syntermes species which are also bigger in size. The Baganda community, who live around the northern shore of Lake Victoria in Uganda use termites and fried grasshoppers as snakes between the main meals (Srivastava et al., 2009).

\section{Entomophagy in India}

The type of insect consumption in different states of India is not documented well till date. Further work is necessary on that aspect. It is found that tribal people of Phek, Dimapur and kohima districts of Nagaland eat grasshoppers, cricket, red ant and larvae of mulberry silkworms. They also eat green colour larvae infested on golmohar tree in the month of March April (Srivastava et al., 2009). Some tribal people of Midnapur district of West Bengal eats red ant eggs, larvae and also uses them as fish bait [personal experience]. Tribal people of Kandhamal, Koraput, Sundergarh, Keonjhar and Mayurbhanj districts of Odisha eat red ant and termite (Srivastava et al., 2009). Termites were collected at the time of swarming, while red ants were collected from the nest formed on the plant. The villagers of Pithra village of Simdega district of Jharkhand eat eggs of Demta, a red ant found on the trees (Srivastava et al., 2009). Tribes in Karnataka and 'Irumbars' tribe in the North Arcot district of Tamilnadu consumed winged termites as food which is commonly called as Eesal (Chakravorty, 2014). In Kerela at least five species of insects (bees, ant and termite) were consumed as food (Chakravorty, 2014). In Manipur, a total of 41 insect species belonging to 8 orders under 24 families and 36 genera are consumed as food. They consumed maximum number of Hemipteran edible insects. Meitei, Tarao, Tangkhul, Chothe and Thadou tribes consume a higher number of species (28-30) in comparison to other ethnic groups in Manipur (Shantibala et al., 2012). In Arunachal Pradesh, the Nyishi and Galo tribes consume at least 81 species of local insects, belonging to 26 families and 5 orders of insects (Chakravorty et al., 2011). The most favourable insect life-stages are the caterpillars and pupae of the mulberry silkworm, Bombyx mori and non-mulberry silkworms (Lepidoptera: Saturniidae), viz. Antheraea pernyi, Antheraea assamensis, Attacus ricini and Samia ricini (Gahukar, 2012). In Meghalaya, sexual forms of termites are consumed as a source of proteins and carbohydrates. Beside this, the mineral content of sexual forms of termite is greater than conventional vegetarian food, salmon fish and broiler chicken (Paul and Dey, 2011). Around 29 species of different edible insects are consumed by tea tribes in greater Chabua of Dibruagarh of Assam (Das et al., 2011). Most of the tribal people of are also habituated with the consumption of Giant water bug (Lethocercus indicus), cricket, locusts, honeybee brood, especially late instar larvae and pupae etc. (Doley and Kalita, 2012). The commonly consumed insects of Assam are Dorylus orientalis, Gryllus sp., Lethocercus grandis, Odontotermes obesus,Apis indica, Vespa sp.,Agabetes 
acuductus or Hydrochera rickseckeri, Heiroglyphus bannian, Neoconocephalus palustris, Philosomia ricini, Antheraea assama, Bombyx mori, Acheta domesticus etc. (Doley and Kalita, 2012; Deva Nath et al., 2005). The Mishings tribe and the Ahom Community of Assam uses Red tree ants (Oecophylla smargdina) as one of the food items during an Assamese Festival Bohag Bihu in the month of April (Doley and Kalita, 2012). It is believed that these insects keep their health free from infection of diseases. The formic acid of these insects is being used in connection with scabies, malaria, tooth aches, stomach disorders, blood pressure anomalies etc. (Chakravorty et al., 2011).

\section{Nutritive value of edible insects}

Besides being a delicious food commodity, the nutritive value of edible insects has attracted the attention of nutritionists, health workers and physicians. Many insects not only have high nutritive value, but are also considered to have health-enhancing properties, such as some caterpillars, ants, termites and silkworms.

Protein is the building block of life and constitutes many important components in body. Insect bodies are also rich protein source. In nearly 100 analysed edible insects (Xiaoming et al., 2010), at egg, larva, pupa or adult stages, the raw protein content is generally $20-70$ percent. Raw protein content is 66.26 percent in Ephemeroptera larvae, 4065 percent in Odonata larvae, 40-57 percent in Homoptera larvae and eggs, $42-73$ percent in Hemiptera larvae, 23-66 percent in Coleoptera larvae and 20-70 percent in Lepidoptera larvae. Protein content of Apidae, Vespidae and Formicidae in the Hymenoptera Order is also high (38-76 percent). After different analytical studies, it is found that the protein content of insects is higher than most plants; the protein content of some insects (e.g. larvae of Ephemerella jianghongensis [66.26 percent], Sphaerodema rustica [73.52 percent]) is higher than that of commercial meat, fowl and eggs and they are highly digestible (between 77\% and 98\%) (RamosElorduy et al., 1997). Finke et al., 1989 reported that the house cricket (Acheta domesticus), when fed to weanling rats, gave better result to get amino acids than soy protein food at all levels of intake.

Fat is an important energy supplier in human body and also supporting and protecting different organs. According to reports and analysis (Xiaoming et al., 2010), many edible insects are rich in fat. The fat content is higher in larvae and pupal stages; whereas it is relatively lower in adult stage. The average fat content of edible insects is between 10 and 50 percent; the fat content of Oxya chinensis of Orthoptera reaches only 2.2 percent whereas in some larvae and pupae of Lepidopteran insects have higher fat content, such as Pectinophora gossypeilla (49.48 percent) and Ostrinia furnacalis (46.08 percent). The fatty acid of edible insects is different from animal fat; it has higher fatty acid that the human body needs, such as that found in the larvae and pupae of Dendrolimus houi, larvae of Musca domestica, Chilo Fuscidentalis and some ants.

Carbohydrates are another important nutritive elements as well as constituent materials of the human body. They can support different physiological functions after conjugate with protein and fat (Jin, 1987). Edible insects mainly content higher amount of protein and fat, but less carbohydrate. The carbohydrate content is varies from 1-10 percent depending on insect type. It is also revealed that insects have considerable amounts of polysaccharide that can enhance the immunity function of the human body (Xiaoming et al., 2010). Chitin, the main constituents of insect body is a macromolecular compound which is 
nutritious and has higher health food value. It can stop bleeding, prevent thrombus and help wounds to heal; it can be made into a medicinal film and can also be used in making cosmetics. The body and skin of edible insects are rich in chitin; different forms of edible insects have different chitin content (5-15 percent), such as Bombyx mori dried pupa content 3.73 percent, defatted pupa content 5.55 percent and Dendrolimus houi pupa content 7.47 percent whereas adult content 17.83 percent (Chen and Fang, 1999).

Inorganic salts, vitamins and trace elements are important components of the human body. They are necessary materials to maintain normal physiological functions of body (Jin, 1987). According to analysed results, edible insects have rich trace elements such as potassium $(\mathrm{K})$, sodium $(\mathrm{Na})$, calcium $(\mathrm{Ca})$, copper $(\mathrm{Cu})$, iron $(\mathrm{Fe})$, zinc $(\mathrm{Zn})$, manganese (Mn), phosphorus (P) and vitamin A, carotene, vitamins B1, B2, B6, D, E, K, C, etc. (Xiaoming et al., 2010). Beef has an iron content of $6 \mathrm{mg}$ per $100 \mathrm{~g}$ of dry weight, while the iron content of the mopane capterpillar is $31-77 \mathrm{mg}$ per $100 \mathrm{~g}$. The iron content of locusts (Locusta migratoria) also varies between 8 and $20 \mathrm{mg}$ per $100 \mathrm{~g}$ of dry weight, depending on their diet (Ooninex et al., 2010). As iron deficiency as the world's most common and widespread nutritional disorder and in developing countries, one in two pregnant women and about 40 percent of preschool children are believed to be anaemic (FAO, 2001). Given the high iron content of several insect species, inclusion of edible insect in human diet can solve the problems in certain way. Zinc deficiency is another important mineral as its deficiency can lead to growth retardation, delayed sexual and bone maturation, skin lesions, diarrhea, alopecia, impaired appetite and increased susceptibility to infections mediated via defects in the immune system (FAO, 2001). It is also found that most edible insects are rich sources of zinc. Beef contents average $12.5 \mathrm{mg}$ zinc per 100 gm of dry weight, while the palm weevil larvae (Rhynchophorus phoenicis) contain $26.5 \mathrm{mg}$ zinc per $100 \mathrm{gm}$ (Bukkens, 2005). Bukkens, 2005 showed that almost all edible insects has thiamine (vitamin B1) ranged from $0.1 \mathrm{mg}$ to $4 \mathrm{mg}$ per $100 \mathrm{~g}$ of dry matter; Riboflavin (vitamin B2) ranged from 0.11 to $8.9 \mathrm{mg}$ per $100 \mathrm{mg}$. By comparison with insects, wholemeal bread provides only 0.16 $\mathrm{mg}$ and $0.19 \mathrm{mg}$ per $100 \mathrm{gm}$ of B1 and B2, respectively. Vitamin B12 occurs only in animal originated food and it is sufficiently present in mealworm larvae, Tenebrio molitor $(0.47 \mu \mathrm{g}$ per $100 \mathrm{~g})$ and house crickets, Acheta domesticus (5.4 $\mu \mathrm{g}$ per $100 \mathrm{~g}$ in adults and $8.7 \mu \mathrm{g}$ per $100 \mathrm{~g}$ in nymphs).

\section{Benefits of rearing insect for food and feed}

As demand for meat rises dramatically, so too does the need for more grain and plant protein. Pimentel and Pimentel (Pimental and Pimental, 2003) calculated that for $1 \mathrm{~kg}$ of high-quality animal protein, livestock are fed about $6 \mathrm{~kg}$ of plant protein. The conversion rates between the feed-to-meat (how much feed is necessary to produce a $1 \mathrm{~kg}$ increase in body mass) is widely vary among animal to animal. Insects require very less feed due to their cold-blooded in nature and do not require feed to maintain body temperature, i.e. the production of $1 \mathrm{~kg}$ of crickets requires only $1.7 \mathrm{~kg}$ of feed (Collavo et al., 2005). When these figures are adjusted for edible weight (usually the entire animal cannot be eaten), the advantage of eating insects becomes even greater than other animal (Van Huis, 2013). Nakagaki and De Foliart, 1991 estimated that up to 80 percent of a cricket is edible and digestible compared with 55 percent for chicken and pigs and 40 percent for cattle.

The benefit of insects can be used as an alternative animal protein source by rearing 
them easily, requiring minimal space. There they can easily increase their population. After that, they can be processed and fed to a specific animal, the meat of which is then sold to the consumer (Veldcamp et al., 2012).

Further this, livestock rearing is responsible for 18 percent of greenhouse gas (GHG) emissions $\left(\mathrm{CO}_{2}\right.$ equivalent), a higher share than the transport sector (Steinfeld et al., 2006). Methane ( $\mathrm{CH} 4)$ and nitrous oxide $\left(\mathrm{N}_{2} \mathrm{O}\right)$ have greater global warming role (GWP) than CO2: if $\mathrm{CO} 2$ has a value of 1 GWP, $\mathrm{CH}_{4}$ has a GWP of 23 and $\mathrm{N}_{2} \mathrm{O}$ has a GWP of 289 (IPCC, 2007). Among insect species, only cockroaches, termites and scarab beetles produce $\mathrm{CH}_{4}$ (Hackstein and Stumm, 1994), which originate from bacterial fermentation by Methanobacteriaceae in the hindgut (Egert et al., 2003). For this reason, they have the potential to become a part of dietary regimen in the Western world include species such as mealworm larvae, crickets and locusts, which compare favourably with pigs and beef cattle in their GHG emissions (Ooninex et al., 2010).

Water is life and lack of water is already constraining agricultural output in many parts of the world. Chapagain and Hoekstra (Chapagain and Hoekstra, 2003) estimated that producing $1 \mathrm{~kg}$ of animal protein requires 5-20 times more water than generating $1 \mathrm{~kg}$ of grain protein. It is expected that less volume of water is required to raise an equivalent weight of edible insects than other livestock. For example, Mealworms are more drought-resistant than cattle.

\section{Economic benefits}

Many communities understand that Insects are a major source of animal protein and are critical for their diet diversification. Further, insects do provide valuable buffers against seasonal shortages of food (Dufour, 1987).
Trade in edible insects is a major source of income in some parts of the World and they provide important livelihood opportunities for many people in developing countries. Rural people can easily maintain their minilivestock, such as insects within their villages and due to their easy transportability; they can easily move to urban markets by bus, truck or bicycle. For example, the indigenous communities of Papua, Indonesia consume between 60 to 100 edible insect species to diversify their dietary needs and surplus insects later sold in markets, such as the black palm weevil (Rhynchophorus bilineatus), which is collected from the sago palm (Metroxylon sagu). One interesting fact that the price of one bag containing 100-120 larvae of Palm weevil fetches US\$ 2.11 in local markets, comparable in value with 20 chicken eggs and $3 \mathrm{~kg}$ of rice (Ramandey and van Mastrigt, 2010). In Mexico, grasshoppers and other edible insects are sold in village markets by pound and many are sold in cans as fried grasshoppers, ants etc. in supermarkets and local grocery stores. Due to their high protein and low fat content they can be fried or ground into meal and mixed with flour to make tortillas. Tortillas are served with red and white agave worms in many Maxico city restaurants (Srivastava et al., 2009). One species in Asia, the giant water bug, is now exported from Thailand to Asian food shops in the United States of America (Pemberton, 1988). There are cricket farms in America, which raise the insects for the pet trade (Srivastava et al., 2009). Ethiopian tribes preserved bugs in salt and later sold them in markets (Srivastava et al., 2009). Examples of insect prices can give an idea of orders of magnitude and are taken from a wide variety of specific cases at the village level, in markets and online. In United Kingdom of Great Britain and Northern Ireland one have to pay $€ 7.50$ for the purchase of $70 \mathrm{gm}$ of weaver ant pupae online. In the Netherlands, $50 \mathrm{gm}$ of the yellow mealworm 
and the lesser mealworm costs $€ 4.85$, and 35 migratory locusts cost around $€ 9.99$ online. In the Lao People's Democratic Republic, the price of grasshoppers is much lower, at approximately $€ 8-10$ per $\mathrm{kg}$. In Oaxaca, Mexico, chapulines sell for around $€ 12$ per kg. Canned white have been exported to Canada and the United States. The cans containing only five or six agave caterpillars and sell for US\$ 50 per kg (Ramos Elorduy et al., 2011; Van Huis et al., 2013).

Eating insects can offer a many choices on the menu due to the presence of their million species (except harmful species) whereas meat animals offer a choice of only a few dozens of them. Many edible insect species such as grasshoppers, caterpillars, termites etc. are quite injurious to our important crop plants. So, eating insect would act as a biological control on these species.

Actually, common prejudice against eating insects is not justified from a nutritional point of view. Insects are not inferior in comparison to other protein sources such as fish, chicken, pork, mutton and chivon. Although some societies still do not taken entomophagy seriously but hopefully in near future they will take them seriously due to their high nutritional value, low environmental impact, low-risk nature (from a disease standpoint) and easily digestible (Pliner and Salvy, 2006).

In early decade, arthropods like lobsters and shrimps considered as poor-man's food in the West, but now appear as expensive delicacies there. Further this, creation of new recipes and tasty menus in restaurants to the design of new food products; the food industry has a bigger role to play in raising the status of insects as food.

To maintain the large number of World population, food production should be increased accordingly. However it will be difficult to increase productivity to a level that satisfies food demand, mainly because of the scarcity of farmland in coming years. This will lead to shortages of food, especially animal protein.

When total food resources are insufficient, it is unwise to feed livestock with grain and other foodstuffs, which can be consumed directly by humans. For this reason, it becomes necessary to look for new sources of animal protein such as insects, which are rich in nutrients, vitamins etc. Most insects are edible, although there are some toxic species and they should be avoiding for consumption.

So, sound knowledge about edible insects is necessary. By this way, insects can take part as a viable option to become a food item for direct human consumption or allowing insects as food additives for provision of protein and other nutrients and encouraging the use of insects as domestic animal (poultry, pig and fish) food.

Good associations and organizations are needed to link between decision-makers, NGOs, scientist and farmers. By offering a common voice to farmers and gatherers - in this case those who are involved in the edible insects sector - they can aid the planning, design and implementation of policies and programmes that directly or indirectly benefit their livelihoods (FAO, 2007).

At last, further research is needed to develop and automatize, cost-effective, energyefficient and pathogen free safe rearing, harvest and postharvest processing technologies as well as sanitation procedures to ensure food and feed safety and produce safe insect products at a reasonable price on an industrial scale, especially in comparison to meat products (Rumpold and Schluter, 2013). 


\section{References}

Bachstez, M. and Aragon, A. 1945. Notes on Mexican drugs, plants, and foods. III. Ahuauhtli, the Mexican caviar. J Am Pharm Assoc, 34: 170-172.

Bukkens, S. G. F. 2005. Insects in the human diet: nutritional aspects. In M.G. Paoletti, ed. Ecological implications of minilivestock; role of rodents, frogs, snails, and insects for sustainable development, pp. 545-577. New Hampshire, Science Publishers.

Cerritos, R. 2009. Insects as food: an ecological, social and economic approach. $C A B$ Reviews: Perspectives in Agriculture, Veterinary Science, Nutrition and Natural Resources, 4(27): $1-10$.

Cerritos, R. and Cano-Santana, Z. 2008. Harvesting grasshoppers Sphenarium purpurascens in Mexico for human consumption: A comparison with insecticidal control for managing pest outbreaks. Crop Prot, 27(3-5): 473480.

Chakravorty, J. 2014. Diversity of Edible Insects and Practices of Entomophagy in India: An Overview. J Biodivers Biopros Dev, 1: 124. doi:10.4172/23760214.1000124

Chakravorty, J., Ghosh, S., Meyer-Rochow, V. B. 2011. Practices of entomophagy and entomotherapy by members of the Nyishi and Galo tribes, two ethnic groups of the state of Arunachal Pradesh (North-East India). J Ethnobiol Ethnomed, 7: 5.

Chapagain, A. K. and Hoekstra, A. Y. 2003. Virtual water flows between nations in relation to trade in livestock and livestock products. Value of Water Research Report Series No. 13. Paris, United Nations Educational, Scientific and Cultural Organization.

Chen, X. and Fang, Y. 1999. The edible insects of China. Beijing, Science and Technology Publishing House. 180 pp.

Cohen, J. H., Sánchez, N. D. M. and Montielishinoet, F. D. 2009. Chapulines and food choices in rural Oaxaca. Gastronomica (Berkeley Calif), 9 (1): 61-65.

Collavo, A., Glew, R. H., Huang, Y. S., Chuang, L. T., Bosse, R. and Paoletti, M. G. 2005. House cricket small-scale farming. In M.G. Paoletti, ed., Ecological implications of minilivestock: potential of insects, rodents, frogs and snails. pp. 519-544. New Hampshire, Science Publishers.

Das, S., Mondeep, C. and Kumar, S. R. 2011. A study on Edible insects used by the tea tribes in Greater Chabua area, Dibrugarh. Abstract of International Seminar on Bioresources and Human Sustenance. Zoology Department, Cotton College, Guwahati, Assam. Pp154.

DeFoliart, G. R. 1999. Insects as food: Why the western attitude is important. Annu Rev Entomol, 44: 21-50.

Del Toro, I., Ribbons, R. R. and Pelini, S. L. 2012. The little things that run the world revisited: a review of ant-mediated ecosystem services and disservices (Hymenoptera: Formicidae). Myrmecol News, 17: 133-146.

Deva Nath, H. K., Robin, G. and Gunjan, G. 2005. Insects as human food with special reference to Assam and North East India. Asian Agrihist, 9 (2): 119127.

Doley, A. K. and Kalita, J. 2012. Traditional Uses of Insect and Insect Products in Medicine and Food by the Mishing tribe of Dhemaji District, Assam, North-East India. Soc Sci Res, 1 (2):11-21.

Dufour, D. L. 1987. Insects as food: a case study from the northwest Amazon. Am Anthropol, 89(2): 383?

Egert, M., Wagner, B., Lemke, T., Brune, A. 
and Friedrich, M.W. 2003. Microbial community structure in midgut and hindgut of the humus-feeding larva of Pachnoda ephippiata (Coleoptera: Scarabaeidae). Appl Environ Microbiol, 69 (11): 6659-6668.

Elvin, C.M., Carr, A.G., Huson, M.G., Maxwell, J.M., Pearson, R.D., Vuocolo, T.,Liyou, N.E., Wong, D.C.C., Meritt, D.J. and Dixon, N.E. 2005. Synthesis and properties of crosslinked recombinant pro-resilin. Nature, 437: 999-1002.

FAO. 2007. Promises and challenges of the informal food sector in developing countries. Rome.

FAO. 2009. Biodiversity and nutrition, a common path. Rome.

FAO/WHO. 2001. Human vitamin and mineral requirements. Rome.

Finke, M. D., DeFoliart, G. R., Benevenga, N. J. 1989. Use of a four-parameter logistic model to evaluate the quality of the protein from three insect species when fed to rats. J Nutr, 119 (6): 864-71.

Gahukar, R. T. 2012. Entomophagy can support rural livelihood in India. Cur Sci, 103:1.

Ghazoul, J. 2006. Mopani woodlands and the mopane worm: enhancing rural livelihoods and resource sustainability. Final technical report. London, DFID.

Hackstein, J. H. and Stumm, C. K. 1994. Methane production in terrestrial arthropods. Proc Natl Acad Sci USA, 91(12): 5441-5445.

Ingram, M., Nabhan, G.P. and Buchmann, S. L. 1996. Our forgotten pollinators: protecting the brids and bees. Global Pesticide Campaigner, 6(4): 1-12.

IPCC. 2007. Summary for policymakers. In S. Solomon, D. Qin, M. Manning, Z. Chen, M. Marquis, K.B. Averyt, M. Tignor and H.L. Miller, eds. Climate change 2007: The physical science basis. Contribution of Working Group I to the fourth assessment report of the Intergovernmental Panel on Climate Change. Cambridge, UK and New York, USA, Cambridge University Press.

Jin, Y. 1987. Food nutrition hygiene. Commercial Press of China. pp. 11-62.

Latham, P. 2003. Edible caterpillars and their food plants in Bas-Congo. Canterbury, Mystole Publications. New Hampshire, Science Publishers.

MacEvilly, C. 2000. Bugs in the system. Nutr Bull, 25: 267-268.

Nakagaki, B. J. and De Foliart, G. R. 1991. Comparison of diets for mass-rearing Acheta domesticus (Orthoptera: Gryllidae) as a novelty food, and comparison of food conversion efficiency with values reported for livestock. J Econ Entomol, 84(3): 891896.

Oonincx, D. G. A. B., van Itterbeeck, J., Heetkamp, M. J. W., van den Brand, H., van Loon, J. and van Huis, A. 2010. An exploration on greenhouse gas and ammonia production by insect species suitable for animal or human consumption. Plos One, 5(12): e14445.

Paul, D. and Dey, S. 2011. Nutrient content of sexual and worker forms of the subterranean termite Reticulitermes. Sp. IJTK, 10: 505-507.

Pemberton, R. W. 1988. The use of the Thai giant waterbug, Lathocerus indicus (Hemiptera: Belostomatidae) as human food in California. Pan Pac Entomol, 64: 81-82.

Pimentel, D. and Pimentel, M. 2003. Sustainability of meat-based and plantbased diets and the environment. Am J Clin Nutr, 78: 660S-663S?

Pliner, P. and Salvy, S. J. 2006. Food neophobia in humans. In R. Shepherd and M. Raats, Eds. The psychology of food choice, pp. 75-92. Oxfordshire, CABI Publishing. 
Ramandey, E. and van Mastrigt, H. 2010. Edible insects in Papua, Indonesia: from delicious snack to basic need. In P.B. Durst, D.V. Johnson, R.L. Leslie. and K. Shono, eds. Forest insects as food: humans bite back, proceedings of a workshop on Asia-Pacific resources and their potential for development. pp. 105-114. Bangkok, FAO Regional Office for Asia and the Pacific.

Ramos Elorduy, J. and Pino, J. M. 2002. Edible insects of Chiapas, Mexico. Ecol Food Nutr, 41(4): 271-299.

Ramos Elorduy, J., Pino, J. M., Vázquez, A. I., Landero, I., Oliva-Rivera, H. and Martinez, V. H. C. 2011. Edible Lepidoptera in Mexico: Geographic distribution, ethnicity, economic and nutritional importance for rural people. J Ethnobiol Ethnomed, 7(2): 1-22.

Ramos-Elorduy, J., Pino, J. M., Prado, E. E., Perez, M. A., Otero, J. L., de Guevara, O. L. 1997. Nutritional value of edible insects from the state of Oaxaca, Mexico. J Food Comp Anal, 10(2):14257.

Rastogi, N. 2011. Provisioning services from ants: food and pharmaceuticals. Asian Myrmecol, 4: 103-120.

Rumpold, B. A. and Schlüter, O. K. 2013. Nutritional composition and safety aspects of edible insects. Mol Nutr Food Res, 57(3)

(DOI 10.1002/mnfr.201200735).

Shantibala, T., Lokeshwari, R. K., Sharma, H. D. 2012. Entomophagy practices among the ethnic communities of Manipur, North East India. IJIIT 5: 13-20.

Shen, L., Li, D., Feng, F. and Ren, Y. 2006. Nutritional composition of Polyrhachis vicina Roger (edible Chinese black ant). Songklanakarin J Sci Technol, 28(1): 107-114.

Srivastava, K. P. 1996. A text book of applied entomology (vol 11). Kalyani publishers. $2^{\text {nd }}$ edition. pp 507.
Srivastava, S. K., Babu, N., Pandey, H. 2009. Traditional insect bioprospecting-as human food and medicine. IJTK 8: 485-494.

Steinfeld, H., Gerber, P., Wassenaar, T., Castel, V., Rosales, M. and de Haan, C, eds. 2006. Livestock's long shadow: environmental issues and options. Rome, FAO.

Van Huis A, Van Itterbeeck J, Klunder $\mathrm{H}$, Mertens E, Halloran A, Muir G, and Vantomme P. 2013. Edible insects: future prospects for food and feed security. FAO forestry paper 171 , FAO, Rome.

Van Huis, A. 2003a. Medical and stimulating properties ascribed to arthropods and their products in sub-Saharan Africa. In É. Motte-Florac and J.M.C. Thomas, eds. Insects in oral literature and traditions, pp. 367-382. Ethnosciences: 11. Société d'études linguistiques et anthropologiques de France (series): 407. Paris, Peeters.

Van Huis, A. 2003b. Insects as food in subSaharan Africa. Insect Sci Appl, 23(3): 163-185.

Van Huis, A. 2013. Potential of insects as food and feed in assuring food security. Annu Rev Entomol, 58(1): 563-583.

Van Lenteren, J.C. 2006. Ecosystem services to biological control of pests: why are they ignored? Proc. Neth. Entomol. Soc. Meet., 17: 103-111.

Veldkamp, T., van Duinkerken, G., van Huis, A., Lakemond, C. M. M., Ottevanger, E., and van Boekel, M. A. J. S 2012. Insects as a sustainable feed ingredient in pig and poultry diets. A feasibility study. Wageningen UR Livestock Research, Report 638.

Xiaoming, C., Ying, F., Hong, Z. and Zhiyong, C. 2010. Review of the nutritive value of edible insects. In P.B. Durst, D.V. Johnson, R.L. Leslie. and K. Shono, eds. Forest insects as food: 
humans bite back, proceedings of a workshop on Asia-Pacific resources and their potential for development. pp. 8592. Bangkok, FAO Regional Office for Asia and the Pacific.

Yen, A. L 2010. Edible insects and other invertebrates in Australia: future prospects. In P.B. Durst, D.V. Johnson, R.L. Leslie. and K. Shono, eds. Forest insects as food: humans bite back, proceedings of a workshop on AsiaPacific resources and their potential for development. pp. 65-84. Bangkok, FAO Regional Office for Asia and the Pacific.

Yen, A. L. 2005. Insects and other invertebrate foods of the Australian aborigines. In M.G. Paoletti, ed. Ecological implications of minilivestock: potential of insects, rodents, frogs and snails, pp. 367-388. New Hampshire, USA, Science Publishers.

Yhoung-Aree, J. and Viwatpanich, K. 2005. Edible insects in the Laos PDR, Myanmar, Thailand, and Vietnam. In M.G. Paoletti, ed. Ecological implications of mini livestock, pp. 415440.

Yong-woo, L. 1999. Silk reeling and testing manual. FAO Agricultural Services Bulletin, 136.

\section{How to cite this article:}

Atanu Seni. 2017. Edible Insects: Future Prospects for Dietary Regimen. Int.J.Curr.Microbiol.App.Sci. 6(8): 1302-1314. doi: https://doi.org/10.20546/ijcmas.2017.608.158 